\title{
Bogusławą Keckova: An Official Female Doctor in Bosnia and Herzegovina, 1893-1911
}

\author{
Husref Tahirović ${ }^{1}$, Brigitte Fuchs ${ }^{2}$ \\ ${ }^{1}$ Department of Medical Sciences of the \\ Academy of Sciences and Arts of Bosnia \\ and Herzegovina, Sarajevo, Bosnia and \\ Herzegovina, ${ }^{2}$ Department of Cultural \\ and Social Anthropology at the University \\ of Vienna, Vienna, Austria
}

Correspondence: husref.tahirovic@untz.ba

Tel.: + 38761720740

Fax.: + 38735303774

Received: 25 July 2019

Accepted: 30 August 2019

Key Words: Official Female Doctors • Bogusławą Keckovą " Mostar • Osvit • Bosnia and Herzegovina 1878-1918.
The purpose of this paper is to bring to light the biographical details, the professional work and the publishing activities of Bogusławą Keckovą (Bohuslava Kecková in Czech and Keck in German), who functioned as an Austro-Hungarian health officer in Mostar from 1893 to 1911 during the period of the Austro-Hungarian occupation of Bosnia and Herzegovina (BH). Keckovą, who came from Prague, was the second of nine female physicians to be employed by the Austro-Hungarian authorities between 1892 and 1918. Keckovą contributed significantly to the improvement of public health and hygiene in $\mathrm{BH}$, especially by organising the medical treatment of Muslim women. She published a series of popular medical articles, both in Czech and in Bosnian. Her medical articles in the Mostar newspaper, 'Osvit', were among the first in $\mathrm{BH}$ to promote public health education and aimed at improving the health of the population. In the Czech Republic, 'Bohuslava Kecková' is renowned for being the first Czech female physician to graduate, who, due to Austria's conservativism and anti-feminism, had been forced to study and practise abroad. After Keckovą's efforts to have her Swiss MD degree (1880) recognised in Austria failed in 1882, she acquired an Austrian midwife's diploma and established a maternity home in Prague. In 1892, she accepted the invitation to serve as an Austro-Hungarian female health officer in Mostar, where she initialised and popularised the utilisation of public health among (Muslim) women. Conclusion. Bogusławą Keckovą’s work as a physician, medical writer and health educator, which she continued tirelessly until her death in 1911, was based on gender-specific socialmedical concepts, which were at the core of the contemporary Czech feminist movement.

\section{Introduction}

Throughout the Austro-Hungarian occupation (1878-1918) of Bosnia and Herzegovina $(\mathrm{BH})$, nine official female doctors were employed in the territory from 1892 onwards $(1,2)$. Bogusławą Keckovą was the second official female physician from the Austro-Hungarian Empire (AHE) to come to $\mathrm{BH}$ and worked in Mostar from 1893 to
1911. At that time, the standard of living was very low throughout $\mathrm{BH}$; public health and hygiene had not yet been introduced and the hygienic standards of the population were poor, particularly in the rural areas. Infectious diseases often had the character of epidemics, and the mortality of the population was significantly high, especially among infants and children. In many aspects, so- 
ciety was based on 'customs', which were deemed to be the best and only way to live, and folk medicine was deeply rooted and often included quackery. The common people believed that 'God had given disease' and that 'God would make the disease disappear'. A special challenge in providing health care to the population involved Muslim women and girls. According to the traditional customs that prevailed at the time, Muslim women should not be treated by male doctors, nor should they receive medical help outside of their own home (3).

Bogusławą Keckovą finished her medical studies in Zürich in 1880 but was denied permission to practice as a physician in the AHE. After having conducted a midwife's practice in Prague, she accepted the offer to enter service as a female health officer (Amtsärztin) in $\mathrm{BH}$ in 1892. As indicated by her official title as a 'Landesärztin (für Herzegowina)' (provincial health officer [of Herzegowina]), her responsibilities involved the treatment of female patients from Mostar and the surrounding area as well as other Herzegovinian districts. From the beginning of her appointment, she worked tirelessly at the medical clarification of her patients. In her earlier years, she frequently visited patients in their homes, as they refused to come to the outpatient clinic; visiting possibly unwelcoming patients at home was even a requirement in the guidelines for female health officers (4).

Keckova pursued a social and educational concept of modern hygiene which, in the AHE, had been first promoted by the Czech feminist movement. Czech feminism advocated women and children's need for female physicians in order to remove the general ignorance of the facts of life that prevailed at the time and to popularise modern medicine, hygienic standards, public health utilisation and a healthy lifestyle among the female population. Based on her experiences as a midwife in Prague and a female health officer in Mostar, Keckovą published popular medical articles that aimed to provide health education in the Czech feminist press from the late 1880s onwards. In $\mathrm{BH}$, she published four comprehensive medical educational articles that appeared in 1904 and 1905 in 'Osvit', a newspaper founded and edited by Ivan Aziz Milićević in Mostar from 1898 to 1907.

In this paper, Bogusławą Keckovą’s life, her professional work from 1893 to 1911 and her publishing activities as a medical educator are outlined more specifically.

\section{Keckovą’s Short Biography}

Bogusławą Keckovą finished her medical studies at the University of Zürich in 1880 and became known as the first Czech (Austrian) female physician to graduate. In the Czech Republic, Keckovą's publicity lags behind Anna Bayerovás prominence as the 'first Czech female physician', which is owed to Bayerovás historical role as the figurehead of Czech feminism. Although Keckovą has been neither forgotten nor omitted from the Czech medical and feminist historiography (5-9), no detailed biography has been dedicated to her memory. Her life and activities have predominantly been the subject of numerous collective biographies of the pioneers of female academic and medical education in the AHE (10).

The Czech historian Ctibor Nečas provided a monograph on the lives and activities of the Austro-Hungarian female health officers who were deployed in $\mathrm{BH}$ as an extraordinary administrative measure to popularise public health utilisation, particularly among the female Muslim population, from 1891 to 1918 (11). He based his short biographical note on Keckovą (12) on an autobiographical account that she had shared with Eliška Krásnohorská, the editor of the Czech femi- 
nist journal, Ženské Listy (13). This principal biographical source for Keckovą̧s life and activities was revised and complemented by Krásnohorská, thus constituting a tribute to Keckovą's absolute commitment to the cause of social medicine designed from and for 'women and children' as the core concern of 19 th century popular Czech feminism.

'Bohuslava Josefa Kecková' was born in Bukol, a small hamlet in the Czech district of Mělník to the northwest of Prague. She was the second of three daughters of the wealthy local landowner and businessman Adolf Keck and his wife Jana Kecková, née Kubičková. In 1862, the family moved to Prague-Karlín, after Bogusławą’s father had sold his estate and acquired a limestone quarry to the south of Prague, in Braník, which would earn him a fortune $(13,12)$. Therefore, Bogusławą and her family spent their lives under materially favourable conditions, which made her efforts to 'support women and children' $(13$, p. 68$)$ a genuine mission that she at no point had to pursue to earn a living. As a girl from the milieu of the emerging Czech nationalist and pro-feminist middle class, Bogusławą was sent to a higher girl's school in Prague and considered to be extraordinarily gifted. According to her own account, she urged her father to allow her to 'continue learning' after she had finished school at the age of 16. Her father arranged for her additional private lessons in all subjects taught at Austrian higher boys' schools. Finally, he also succeeded in persuading the principal of the famous Czech Malostranské Gymnasium in Prague to permit Bogusławą to take the exam for general qualification for university entrance (Matura) (13). Keckovą took her Matura exam privately at the sports hall of the same school in July 1874 (13), thus becoming the first girl in the AHE to qualify for academic studies.

Although Austrian medical faculties did not accept female students prior to 1900 , some Swiss universities did, particularly the 1833-founded University of Zürich, where women were admitted to all courses from the 1840s onwards. In October 1874, Keckovą travelled to Zürich accompanied by her father and enrolled at the university to study medicine (13). Keckova claimed that she learned 'easily', and she was awarded her MD degree on August 4, 1880. Her thesis on the statistics of struma operations (14) was dedicated to Edmund Rose (1836-1914), university professor of surgery in Zürich, who had chosen her as his assistant physician (13). At an earlier point, she had also assisted at the clinic of gynaecology (13). Keckovą returned to Prague immediately after graduation. According to Nečas (12), she seemed to be convinced that she would succeed in publishing her thesis and establishing her own doctor's office in Prague. Both goals, however, proved to be unachievable. Her expertise was neither acknowledged by the association of Czech physicians nor was her Swiss degree recognised in Austria (12). After two years of intervening with the academic and administrative authorities and filing lawsuits at the different courts, in 1882, she received the negative decision of the $\mathrm{Su}$ preme Court in Vienna purporting that her femininity excluded her from the right to practice as a physician in Austria $(12 ; 13)$. Forced to change her plans, Keckovą initially considered settling in Hungary, where female physicians were admitted practicing when male physicians were unavailable (12). However, she ultimately chose the second option available to her, which meant to abandon her MD qualification. Still in 1882, she travelled to Vienna to attend a midwifery course at Vienna University's medical faculty, which entitled her to work as an Austrian midwife. Based on the wealth that she and her sisters had inherited from their father, who died in 1880, Keckovą established a maternity home in Prague in 1883, where 'women of all classes' were welcome (8). Krásnohorská (8) later highly praised 
Keckovą's activities as a midwife, emphasising her philanthropic practice of also taking care of destitute women, whom she treated free of charge, even providing for their medication at her own expense. Krásnohorská remarked that Keckovą's maternity home was 'unusually popular', the 'Czech ladies' rushing to her like 'the faithful to a wonderworking spring' (8). According to Krásnohorská, Keckovą, as a 'genuine democrat', had abandoned all professional pride in order to 'support her Czech sisters as a midwife.' Krásnohorská considered Keckovą’s final appointment as a female health officer in $\mathrm{BH}$ to be a 'gratification and triumph' of the Czech women's movement (8).

Keckovą reported that she had been unexpectedly invited by the Austro-Hungarian administration in $\mathrm{BH}$ in November 1892 to assume the newly-created position of a ' $\mathrm{fe}$ male health officer (Landesärztin) of Herzegovina'. As documented by Nečas (12), two positions for female health officers in $\mathrm{BH}$ had been created and advertised regularly in the same year. Since none of the five applicants with Swiss MD degrees met the official requirement to be a native speaker of a Slavic language, the administration of $\mathrm{BH}$ took the initiative to enquire about the vocational aptitude of the second Czech female physician, Keckovą, with the association of Czech physicians. After the latter had consulted the Czech women's association, Keckova was recommended for the office (8). Keckovą accepted 'with pleasure' (13), giving up her life and work in Prague immediately and without hesitation. On January 1, 1893, she headed for Mostar, interrupting her journey in Vienna for an audience with BH's de-facto governor, Bénjamin de Kállay, and in Sarajevo, to be introduced to the Austro-Hungarian supreme medical officer, Joseph Unterlugauer. On January 11, she arrived in Mostar, where she was introduced to the local religious and secular dignitaries. Two days later, she was sworn into her still provisional office, which obliged her to wear an Austro-Hungarian 'military blouse with three rosettes' (12). Her appointment for life followed in 1896. As a health officer for Herzegovina, she was officially responsible for the women and children of a population of roughly 220,000 people (13). Keckovą, as we later elaborate, performed her medical duties and educational activities in Herzegovina tirelessly for 18 years. Suffering from diabetes, she spent her annual six-week leave, besides family visits, on health cures in Karlovy Vary. In the autumn of 1911, her health condition suddenly deteriorated to a degree that she travelled again to the Czech lands. She died on October 17, 1911, in her elder sister's house in Kostomlaty nad Labem, where she was buried in her parents' tomb $(7,12,15)$.

\section{Keckovás Professional Activities in BH}

From 1898 onwards, Keckovą shared the official annual reports that the female health officers in $\mathrm{BH}$ were required to submit (16, $17,18)$ in a processed form with the Czech women's journals, Ženské Listy $(13,16,19)$ and Lada (20). These unofficial reports reveal her 'bottom-up' approach to a job that, in modern terms, might be described as the task of a development worker. Based on her experience as a midwife to 'women of all classes' in Prague, Keckovą seems to have been well-prepared for the eventuality that Herzegovinian women would neither promptly seek her medical help nor closely observe her professional advice. She reported having had the inspiration to 'talk' to the Muslim officials of Mostar and was soon asked by the local Mufti to treat his wife, who had been in need of medical attention for a long time. When her treatment of this 'Muftinica' proved to be a success, she began to receive invitations to consultations in the houses of the wealthy Muslim ladies of the region, and subsequently, her clinic was increasingly frequented by the local 
common women (13). According to the official statistics, Keckovą treated 710 patients in 1893, 763 in 1894, 829 in 1895, 925 in 1896 and 987 in 1897 (13), all of whom were 'women, female adolescents and children'. In 1904, she reported having treated 9,102 patients over the 10 -year period of her stay, roughly half of whom were Muslims (16). These statistics include women and children from different Herzegovinian areas where Keckovą was detailed to practice during official trips. At a later point, she spoke of the 'annual six-week trips' that she undertook after 1895, accompanied by two gendarmes and a local Muslim guide, who organised the announcement of the 'doctorica's' arrival in the villages (19). These trips also served to allow Keckovą to carry out her official duties of vaccinating children and combating regionally widespread infectious diseases, particularly endemic syphilis. ${ }^{1}$ Despite representing the unpopular Austro-Hungarian authorities, Keckovą enjoyed her increasing respect and popularity in Mostar and throughout the country. She reported having been fetched by mostly remotely-living rural people. Her latest official report gave the number of 1,213 patients who had sought her advice and treatment in 1909 (19).

Her popularity is also demonstrated by the numerous gifts that she received from her patients and students. She gathered the folk jewellery, handkerchiefs and scarves embroidered with silver and gold thread, clothes made from fine linen and lightweight cloth woven on traditional looms into a collection, which she donated to the National Museum in Prague (8) (Picture 1). ${ }^{2}$ Her col-

${ }^{1}$ It was the locally widespread occurrence of not sexually transmitted syphilis ('Frenjak') in $\mathrm{BH}$ that prompted the Austro-Hungarian authorities to create the office of female health officers, who at first were required to perform genital examinations of Muslim women, who, according to the standards of Bosnian Muslim leaders, were not allowed to be examined by male doctors $(21,22)$.

${ }^{2}$ Krásnohorská (8), however, complained as early lection included a considerable number of photographs, which demonstrate her serious interest in the local handicraft related to her apparent personal taste for needlework.

In 1900, the authorities expanded Keckovą's scope of duties to include the office of a school physician at the higher girls' school in Mostar. ${ }^{3}$ She was simultaneously charged with the task of preparing courses for prospective midwives at the same school, Keckovą herself teaching anatomy, anthropology and nursing care in the Bosnian language $(16,19)$. Her personal educational commitment is underlined by her private initiative to promote literacy among local Muslim girls from 1893 onwards. According to Keckovą, the daughters of Muslim families, if at all, attended only girls' religious schools, which did not teach them how to read and write. ${ }^{4}$ Since the local Muslims were opposed to her suggestion to allow girls to learn how to write, she organised private lessons in 'reading Croatian', arithmetic and needlework, which occasionally met Muslim fathers' approval. In 1904, she

as 1924 about the 'deplorable condition' of the photograph collection.

${ }^{3}$ The employment of school physicians who should monitor the pupils' health and teach them hygiene in Austrian schools had been urged by the AustroHungarian pioneers of social medicine, among whom Czech patriots and feminists were prominent. Keckovą's appointment as a school physician was an Austro-Hungarian school pilot project in $\mathrm{BH}$, the office of school physicians being introduced to Austria only in 1909/1910.

${ }^{4}$ Keckova states that local Muslim (elite) men expressed the attitude that women and girls were not allowed to "study the Quran" and, therefore, did not learn how to read and write Arab letters (13). The correctness of this statement is questionable, however, since the sense of attending a "religious school" must have been the study of Quran and, therefore, how to read (and write) Arab.

${ }^{5}$ Today, "Croatian" is considered the language of Croats living in Bosnia and Herzegovina. Muslims (Bosniaks) call the same language Bosnian. Kecková called the local language "Croatian" regardless whether the speakers were Serbs, Croatians or Muslims (Bosniaks). 

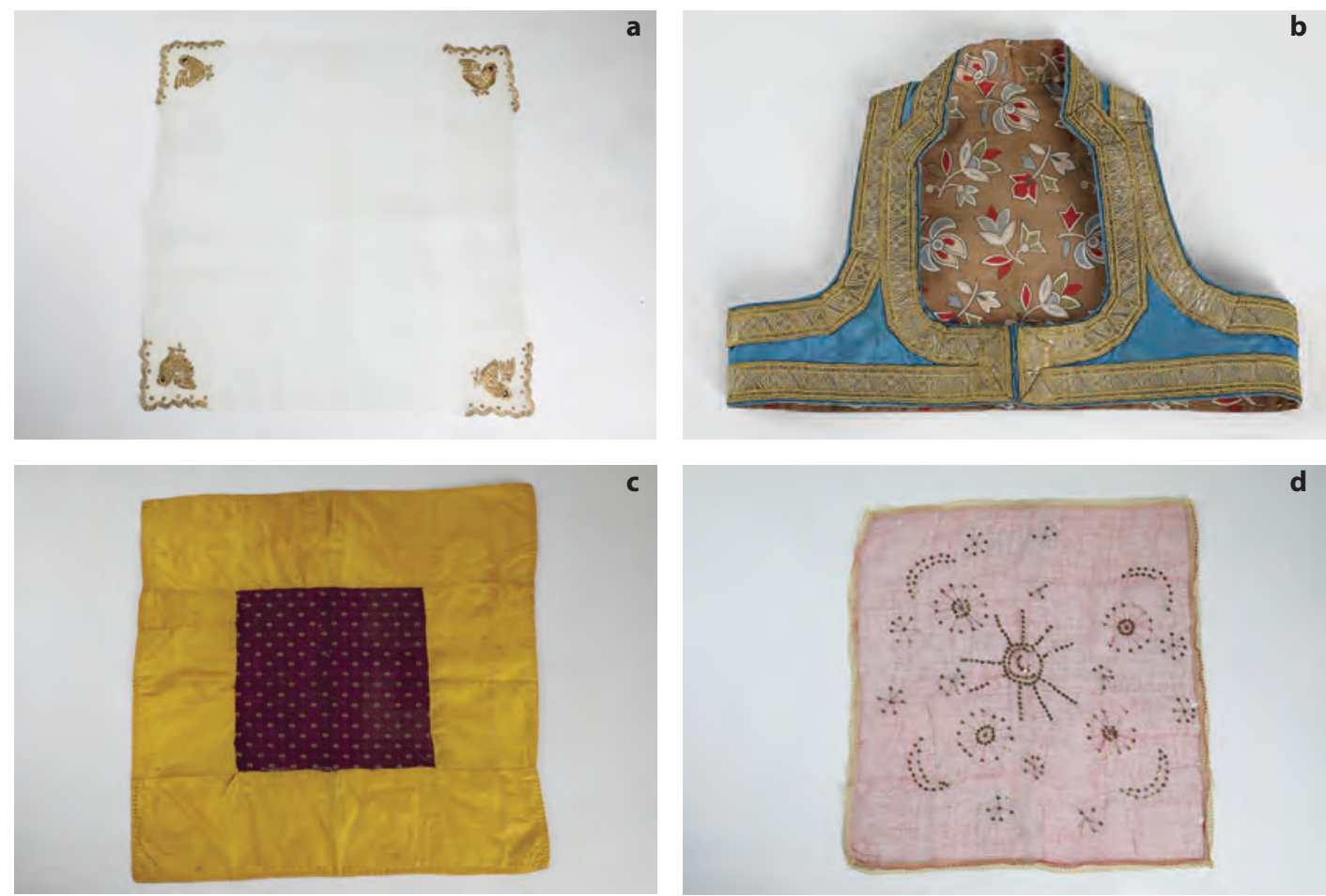

Picture 1. A: Scarf, decorative, of starched white muslin, embroidered in four corners with gold thread on both sides fully, the edge of the corner is trimmed. Motif: bird (Inventory no.: H4-NS3505, Collection of the National Museum, Prague, Czech Republic); B: "Children's waistcoat called 'barley', a miniature display of light blue silk, decorated around the edges with a gold portico, lined with printed chintz (Inventory no.: H4-NS3552, Collection of the National Museum, Prague, Czech Republic); C: A silk blanket called 'bošča', sewn a square of purple silk in the middle with a yellow woven pattern - purple and yellow flowers. There is yellow silk around the purple stripe. The blanket is lined with white cloth. Gifts are wrapped in the blanket during baptism (Inventory no.: H4NS3523, Collection of the National Museum, Prague, Czech Republic); D: Ceremonial wedding shawl, made of red sparse cotton fabric in the manner of soft organza, decorated with gold coins, the region is lined with yellow machine lace. So-called 'telija' bridal veil bride (Inventory no.: H4-NS3516, Collection of the National Museum, Prague, Czech Republic).

reported home that she had thus far been able to recruit 37 young Muslim women and girls, whom she taught obviously the virtues of a modern 'Bosniak' identity (16). Keckovą’s commitment was rewarded with the affection that she enjoyed in Mostar (15), and, on the part of the administration, with her repeated official commendation by the de-facto governor, de Kálley (8).

\section{Keckovą’s Publishing Activities}

As the first female medical doctor in the AHE, Keckovą did not have the option of publishing scientifically. ${ }^{6}$ She had published articles of literary and medical content from the 1880s onwards in the Czech feminist press, predominantly in the Czech women's magazine, Lada, which was introduced in 1889. Keckovą̧s preference for Lada seems to be due to the fact that Ženské Listy called for the opening of higher education for women in the AHE, while Keckovą preferred the es-

\footnotetext{
${ }^{6}$ Contemporary male supporters of the idea of 'women's need of female physicians', in fact, tended to conceptualise female doctors as academically trained midwives, because midwives served throughout the $19^{\text {th }}$ and early $20^{\text {th }}$ century as the main health care providers for the common people.
} 
tablishment of separate universities for girls and women, 'as in Russia and the United States' (13). When she depicted rural women's work in agriculture as an obstacle to a healthy lifestyle, which she conceptualised as requiring the full-time work of a well-informed and qualified housewife and mother, she proved to be a follower of 19th century moderate feminism. This movement assumed a detrimental effect of women's double and triple burden as workers, mothers of numerous children and caretakers on female health and aimed at transforming working women into domestic, voting 'agents of modern health and hygiene' rather than at gender equality. Keckovąs mission to popularise medical and nursing knowledge among women, girls and pupils corresponds with the contemporary middle-class feminists' social-medical reform movement, which drew on sources such as Florence Nightingale's hygienic standards in nursing (23) and popular medicine (24). Keckovą was convinced that the introduction and dissemination of hygienic standards were the most important means to prevent and contain diseases. In BH, Keckovą reported on her continuous attempts to persuade her (former) patients to prepare healthier meals and take care of their personal hygiene as well as the hygienic condition of their living spaces and garments (16). Lada printed Keckovą's remarks on female health education, nursing care, achieving a balanced diet, and healthy living and ways to dress (13).

In the Bosnian language, Bogusławą Keckova published four medical articles of similar content in the 'Society and Science' section of the Mostar newspaper, 'Osvit.' These articles are entitled 'Raising Healthy Infants' (1904), 'Man and His

${ }^{7}$ Ivan Aziz Milićević (1868-1950), Bosnian journalist and writer. http://bosnae.info/index. php/knjizevni-dvojac-osman-nuri-hadzic-ivanmilicevic-jedinstven-kulturoloski-fenomen-uhistoriji-bosanskohercegovacke-knjizevnosti
Health' (1905), 'Caring for Patients at Home' (1905) and 'About Tuberculosis, and How It Can Be Contained' (1906) and convey an impression of the state of public health and hygiene in the Mostar district and the health consciousness of the local population at that time. Keckovą's familiarity with the local population's social conditions, health culture and local customs allowed her to address the specific challenges to public health and hygiene that she had observed and to formulate practical suggestions for improvement. Keckovą, therefore, is the author of the first popular medical articles ever published in $\mathrm{BH}$. (Please see the supplementary material entitled: Medical Articles in the Mostar Newspaper 'Osvit'.)

\section{Concluding Remarks}

Bogusławą Keckovą/Bohuslava Kecková is known in the Czech Republic, her native country, as the first female physician to graduate but who was not permitted to practice at home. As a female member of the prosperous Czech 'patriot' middle class, Keckovą was strongly influenced by the Czech feminists' claims for a social/social-medical reform triggered by female physicians designed to treat women and children 'of all classes'. Keckovą evidently internalised this aspiration and considered bringing medical help to whomever and educating 'women and children' in modern hygiene and public health utilisation to be her personal mission. When she was denied the right to practice as a physician in Austria in 1882, she decided to work as a midwife in Prague (1883-1892). When the Austro-Hungarian authorities of occupied BH invited her in 1892 to assume the office of a female health officer for Herzegovina in Mostar, she accepted without hesitation. Arriving in Mostar in January 1893, she continued her mission in $\mathrm{BH}$, where she worked as a physician, instructor of midwives and health educator until her 
death in 1911. She published educational articles in popular magazines and newspapers, both in Czech and in Bosnian, which she based on her extensive professional and health education experience in $\mathrm{BH}$. Her familiarity with the local population's social conditions, health culture and local customs allowed her to address the specific challenges to public health and hygiene that she had observed and to formulate practical suggestions for improvement.

\section{References}

1. Nečas C. Activities of the official female doctors in Bosnia and Herzegovina 1892-1918 [in Bosnian]. Istorijski zbornik Instituta za istoriju u Banjaluci. 1988;(9):91-110.

2. Martin B. List of 9 medical officers appointed by Austria-Hungary in Bosnia-Herzegovina 18921918 (taking into account the future career path of female doctors) [in German]. [cited 2019 Jul 9] Available from: https://www.scribd.com/document/336593960/Liste-der-9-von-Osterreich-Ungarn-eingesetzten-Amtsarztinnen-in-BosnienHerzegowina-1892-1918-unter-Berucksichtigung-des-spateren-Berufsweges-der-Ar-

3. Kujović M. Activities of the Austro-Hungarian government and public health authorities in Bosnia and Herzegovina regarding the supresion of endemic syphilis (1878-1910) [in Bosnian]. Zbornik radova: Izvori za prikupljanje i istraživanje podataka o zdravstvenoj i socijalnoj kulturi s posebnim osvrtom na kanton Sarajevo i šire. Sarajevo: Zavod za javno zdravstvo $\mathrm{BiH}$; 2011. p. 177.

4. Public Health in Bosnia and Herzegovina 18781901 [in German], ed. by Landesregierung für Bosnien und die Hercegovina. Sarajevo: Landesdruckerei; 1903. p. 17.

5. Dr. Bohuslava Kecková, doctor in Mostar [in Czech]. In: Vilímek, JR. editor. Národní album. Sbírka podobizen a životopisů českých lidí prací a snahami vynikajících i zasloužilých. Prague: J.R. Vilímek; 1899. p. 341-342.

6. Bohuslava Kecková [in Czech]. In: Navrátil M, editor. Almanach českych lékařů. S podoboźnami a 1000 zivotopisy: na pamet 50leteho jubilea spolku a časopisů lékařů českych: Nakl. Spisovatelovym; 1913. p. 138.
7. Grossmanová Brodská L. Med. dr. Bohuslava Kecková [in Czech]. Lada. 1912;1[January 1]:4 and Lada. 1912;2[January 15]:16.

8. Krásnokorská E. In memory of the second Czech (female) physician [in Czech]. In: Honzakova A, editor. Československé studentky let 1890-1930. Almanach na oslavu ctyřicátého výroči založení ženského studia Eliškou Krásnohorskou. Praha: Ženská Národni Rada a Spolek Minerva; 1930 [O. 1924]. p. 45-50.

9. Matoušek O. Physicians and naturalists at the time of [J.E.] Purkyně [in Czech]. Prague: Státní zdravotnické nakladatelství; 1954.

10. Bolečková I. The complicated way of women for acknowledgement. The women in professional medicine in years 1900-1939 and the reflection of their acceptance in the professional media discursus [in Czech]. University of Pardubice: Bachelor thesis, Pardubice; 2013.

11. Nečas C. Among Muslim Women. The activities of the female health officers in Bosnia and Herzegovina, 1892-1918 [in Czech]. Brno: Masaryk University, 1992.

12. Nečas C. Bohuslava Kecková, MD, female health officer in Mostar [in Czech]. DVT dějiny věd a techniky. 1985;18(1):25-40.

13. Anon. [Kecková B./Krásnohorská E.]: MD Bohuslava Kecková, Bosnian-Herzegowinian provinical physician in Mostar [in Czech]. Ženské Listy. 1898;26(4): 66-70; 90-93.

14. Keck B. On struma bronchotomies: a contribution to its statistics [in German]. MD thesis, Zürich: University of Zürich; 1880.

15. Řeháková A. Memorial [in Czech]. Ženský svět. 1911; 15(21):323-6.

16. Kecková B. My ten-year medical activity (reports Bohuslava Kecková, female health officer in Mostar) [in Czech]. Ženské Listy. 1904; 32:125-6; 157-60;186-17;205-29;230-3.

17. Anon. Female Physicians in Bosnia (according to official sources) [in German]. Wiener Klinische Rundschau, Feuilleton. 1896;10(30):1349-51.

18. Keck B. Annual report of the female health officer MD Bohuslava Keck about her activity in Mostar in 1897 [in German]. Wiener Klinische Rundschau. 1898;12(31):501-2.

19. Anon. Report on the medical activities of our compatriot MD Bohuslava Kecková, female halth officer in Mstar [in Czech]. Ženské Listy. 1910;38:42-4.

20. Anon. The medical activities of MD B. Kecková [in Czech]. Lada. 1903;4:3:43. 
21. Anon. The eridication of syphilis in Bosnia and Herzegowina [in German]. Internationale Klinische Rundschau. 1912;31:32;509-10.

22. Fuchs B. Orientalising Disease. Austro-Hungarian Policies of Race, Gender, And Hygiene in Bosnia and Herzegovina, 1878-1914. In: Trubeta, Sevasti, Marius Turda and Christian Promitzer, editors: Health, Hygiene and Eugenics in Southeastern Europe until 1945. Budapest: CEU Press; 2011; p. 57-85.

23. Nightingale F. Notes on Nursing: What it is and What it is Not, 2nd edition. London: Harrison, 1860 [1859].

24. Fischer-Dückelmann A. Women as Family Doctors. A medical reference book [in German]. Stuttgart: Süddeutsches Verlags-Institut; 1911 [1901].

Authors' Contributions: Conception and design: HT and BF; Acquisition, analysis and interpretation of data: BF and HT; Drafting the article: HT and BF; Revising the article critically for intellectual content: HT and BF; Approved final version of the manuscript: $\mathrm{BF}$ and $\mathrm{HT}$.

Conflict of Interest: The authors declare that they have no conflict of interest.

\section{Supplementary material}

\section{Medical Articles in the Mostar Newspaper 'Osvit'}

In the Bosnian language Bogusławą Keckovą published four medical articles in the 'Society and Science' section of the Mostar newspaper 'Osvit ${ }^{8}$ The first article was entitled 'Raising Healthy Infants', the second was 'Man and His Health', the third, 'Caring for Patients at Home' and the fourth, 'About Tuberculosis, and How It Can Be Contained ' These were the first articles in $\mathrm{BH}$ with health education content published in a newspaper with the aim of raising the level of he-

${ }^{8}$ Ivan Aziz Milićević (1868 - 1950). Bosnian Journalist and Writer. http://bosnae.info/index. $\mathrm{php} /$ knjizevni-dvojac-osman-nuri-hadzic-ivanmilicevic-jedinstven-kulturoloski-fenomen-uhistoriji-bosanskohercegovacke-knjizevnosti alth culture and improving the health of the wider population.

Raising Healthy Infants was the first article published in the 'Osvit ${ }^{\text {'9 }}$ newspaper in installments. In the introductory part of this article, Dr. Bogusława Keckovą writes about the importance of nutrition of infants from the perspective of the wider community, about the happiness of parents when their infants are healthy and advanced, and about their misfortune when they are ill, about their illnesses and mortality in the world, pointing out that the cause of mortality in the first year of their life is 'inappropriate and insufficient food:

She pays particular attention to breastfeeding and the negative effects of artificial nutrition, and points out that hindrances and exceptions to breastfeeding are not quite as common as many women think, and that barely a tenth part of these imaginary' exceptions are justified. Furthermore she states, in an advisory manner, that when there are justified hindrances to feeding infants a strong breastfeeding woman should be engaged ('wet nurse') and when those opportunities have been exhausted the only thing that remains is to accept artificial nutrition.

This is followed by a range of tips on how to prepare cow's milk, a meal schedule, the delusions of mothers about the causes of crying in infants who are fed with cow's milk, on the unnecessary use of various teas instead of water to dilute milk, and the possible consequences of giving milk prepared in this way to infants. The chapter ends with a text about the serious consequences of long-term feeding with rice flour and similar surrogates.

Hereinafter, Dr. Keckovą talks about nurturing a newborn, listing the most common

${ }^{9}$ Keckovą B. Raising Healthy Infants. Osvit.1904; 7(88):3-4.; Osvit.1904;7(90):4.; Osvit.1904; 7(91): 4.; Osvit.1904;7(93):3.; Osvit.1904; 7(94):4.; Osvit. 1904;7(98):3.; Osvit.1904; 7(10):3. 
mistakes she has learned about in dealing with patients who caused the newborn to become ill, sometimes with a fatal outcome, and she provides a range of tips on how and in what way to achieve and maintain a healthy environment for a newborn which will allow their normal growth and development.

This part of the text also discusses teething with a note that the teething follows the period of illnesses of the child followed by various signs and symptoms until all milk teeth erupt, but that a small number of these illnesses originate from tooth eruption, while other illnesses have other causes. Late tooth eruption is discussed in particular and the text indicates that it is commonly caused by malformation of the bony system, or the existence of rickets. Thereafter she describes her understanding of unnecessary and inappropriate methods which parents still use to support tooth eruption, noting that reasonable parents do not ask for jaw incision any more as was practised before.

The article ends with a text on 'child care in the family' which mainly discusses the nutrition of a child in the second year of life. The following section states that sour, spicy and irritating dishes, as well as spirits are not given to a child at that age. It is interesting that the author immediately makes an exception for spirits, stating: 'in the early childhood years, we can give them spirits, but only a small amount, diluted with water and very rarely'. However, Dr. Keckovą immediately points out that in this respect, many mistakes are made in areas where wine is made and where the adults mistakenly think that the children's teeth will come out more easily after giving them wine, or that children will learn to walk more easily, etc. if they take a little bit of wine with each meal. In the remaining text of this subchapter Dr. Bogusława Keckovą points out that it takes a long time to prepare liquid, nourishing and tasty food and, if it is not wellprepared, even the best dishes become less good and tasty, stating that this often happens in the homes of farmers, where the woman's cooking skills are still low-leveled because of their involvement in cultivating the fields and grooming livestock.

Man and His Health is the second article by Dr. Bogusława Keckova published in the newspaper 'Osvit ${ }^{\prime}$ in installments. The first chapter is entitled Housing. The author describes housing as the place where people live, the place which protects them from external influences and disasters, a place that should be airy, spacious, bright and arranged according to each person's wishes.

The text about air begins with the sentence: 'We always need clean air; it is a major requirement of a healthy life, therefore even though a person cannot live from the air itself, one can do without it even less.' In addition, the author describes the procedures that people used to refresh the air in the apartment, such as burning spruce or other spices and here she gives her critical opinion: 'If the window remains open for the same length of time that these fragrances were burning, then the stench would be removed and the room would be filled with clean and fresh air. 'To be more convincing to readers of the newspaper 'Osvit' she states the opinion of the English writer Miss Nightingale $^{11}$ from her famous work about

\footnotetext{
${ }^{10}$ Keckovą B. Man and His Health. Osvit.1905;8(2):3.; Osvit.1905;8(4):3.; Osvit.1905;8(5):3.; Osvit.1905;8(6): 3.; Osvit.1905;8(12):3-4.; Osvit.1905;8(12):4.; Osvit.1905; 8(13):3.; Osvit.1905;8(15):3.; Osvit.1905;8(17):3.; Osvit. 1905;8(20):3.; Osvit.1905;8(21):3.; Osvit.1905;8(22):3.; Osvit.1905;8(25):3.; Osvit.1905;8(26):3.; Osvit.1905;8 (27):3.; Osvit.1905;8(30):3.; Osvit.1905;8(31):3.; Osvit. 1905;8(32):3.; Osvit.1905;8(34):3.

${ }^{11}$ Florence Nightingale (1820-1910). During the Crimean War, she and a team of nurses improved the unsanitary conditions at a British base hospital, reducing the death count by two-thirds. Her writings sparked worldwide health care reform. In 1860 she established St. Thomas' Hospital and the Nightingale Training School for Nurses. She died August 13, 1910, in London. https://www.history.com/topics/womenshistory/florence-nightingale-1\#section_2
} 
health care: 'Where there is a stench there is a waste of health and money, therefore, never dwell in such a house.'

Thereafter, she describes places and position where a house should be built, the arrangement of the rooms in apartments, the places where the windows should be placed etc. Dr. Bogusława Keckova devotes special attention to the ventilation of the apartment, its dryness and humidity, the formation of unclean air and its harmful effects on the human body. At the same time she highlights the danger of unclean air in rooms such as halls for school children and inns for adults, where the air is not only polluted by carbon dioxide but also other pollutants such as vapors, dust and tobacco smoke. As one of the preventive measures for polluted air in inns, the author asks for a resolution from the authorities, so that besides just issuing a license to work, they require a test of integrity and the good management of inns so they are provided with the necessary ventilation. This section ends with an overview of the health problems that most often arise from local pubs where the air conditions are limited and unfavourable. Further in the text the origin of moisture in the apartment is described and its adverse effects on human health, i.e. how frequently various diseases are generated in the wet apartments in comparison to dry apartments. This is followed by short texts about light in the apartment which the author begins with the old proverb: 'Where the sun can't go, that's where the doctor comes in' by which the author wishes to accentuate the importance of sunlight for human health; and heating of apartments which begins with a warning about prevention of the generation of the 'fiercest' poisons of carbon monoxide and carbonic acid in heat-generating devices due to their improper use, stating that despite the fact that this is often spoken about as fatal, it still occurs; and about the temperature of the patient's room and heating devices and their place in the apartment, as well as the ventilation of the heated rooms. The following text is about the colors with which the apartment is painted and the author writes about the colors that make the apartment more comfortable and those that make it uncomfortable, the poisons found in the paints or wallpapers covering the walls, which cause poisoning or diseases which are frequently fatal, citing as an example arsenic toxic substances contained in paint and wallpapers.

The next chapter is entitled Clothing, with an introduction in which author talks about creating heat in the body, the range of normal human body temperatures, the body's reaction to the ambient temperature, i. e. about the role of clothing in regulating body temperature. Dr. Bogusława Keckovą further writes about woven materials and the types from which clothing is sewn, and their effect on body temperature and human health. The influence of colour on the regulation of body temperature is especially emphasized, as well as the health hazards of toxic substances found in the colours with which the fabric is dyed, and the clothing of patients which may transmit 'germs of disease' to the healthy population, and the necessity for disinfection.

The following text, entitled Kinds of the Clothing is dedicated to clothing used for certain body parts, the consequences of its improper use and the negative effects on human health, all of which is supported by the customs that people kept and nurtured. The final text of this chapter is entitled Beds. The author calls them 'night-suits' and writes about the importance of maintaining hygiene of all its parts. As in other parts of the text, she critically comments on irregularities in the use of beds which she had observed during home visits to the sick, and further explains how certain 'irregularities' affect health, explaining the common mistake of warming beds, as well as the use of heavy feather beds and duvets, both in win- 
ter and summer, which suck up the vapors of bodies which are not easily discharged from them.

The chapter entitled About Movement discusses in the introduction the importance of movement in the newborn for its further psychomotor development, pointing out that 'the child must be given the opportunity for his limbs to stretch and stretch without obstruction' and points to the example of the English: '... who leave their children for hours lying on their rugs and they can roll at will, which contributes more to the tremendous development of their children than the most cautious caregiver and or nanny, who wrap their children tightly, so that they cannot move for hours, and carry them around the room.'

The following text, Children's Mental Development, considers the importance of movement for children's mental development. Then, with a great deal of criticism the author looks back on the need for early school attendance, in respect of whether the child's mental and physical development has reached the level to enable them to meet school requirements. In doing so, she does not hesitate to mention the fact that '... the beginning of school should not be determined by a certain age, but rather by the child's mental and physical development', pointing out that , '... the sixth year is too early and the child would profit more if they had another year to devote to their development.'

In continuation of the text about school she states that there is a general complaint about school regarding 'overloading children with educational activities' as a real issue. She states: '... it would undoubtedly be more appropriate and healthier for the physical development of children, if they went to school for only two hours instead of 6 or even 8 hours a day, where they are squeezed behind their school desks'. However, Dr. Bogusława Keckovą quickly relin- quishes this interesting reasoning with the explanation: 'The present time places great demands on the individual, social life has evolved so much that the simplest occupation requires much more knowledge than before' and she goes on to explain why it is difficult to change school laws, stating that: '...it is still not possible to stand against the current of time and carry out a thorough revision of school institutions' but she notes that it is necessary to fight for clean air and enough light in school classrooms. She also states that sitting for long periods of time in classrooms has harmful effects on children's bodies, and points out the necessity of exercising with special focus on posture. This section ends with advice about how children should be educated, emphasizing in particular 'the development of independent thinking which is the foundation of later life. The following text is about School Diseases in which the author talks about spinal distortion, nearsightedness and the occurrence of goiter, a common disorder in children at school. Attributing these illnesses only to '... inconvenient school seating' is questionable for Dr. Bogusława Keckovą, because she sees the causes in the lack of care and supervision of children by their parents and teachers.' The author further points out that spinal distortions as well as nearsightedness cannot be easily repaired later and that the onset of these disorders: '... must be limited in development ... with particular emphasis on exercise and adequate nutrition. It is interesting that goiter, which at that time was a common illness in school children in Bosnia and Herzegovina, is not mentioned further in this text.

There follows a description of the importance of systematic exercise for the health of school children and the views of parents on its practice in school. According to her knowledge, parents, especially those from villages, find school exercise unnecessary because they believe that rural children have 
enough physical activity in the fields and vineyards. However, Dr. Bogusława Keckovą believes that this is a consequence of parents ignorance about the importance of systematic exercise for their children's health. She believes when when this is resolved, with good supervision the resistance to exercise will disappear.

The chapter entitled Occupation talks about the impact of work on the health of a person. It starts with a text about household tasks and work, which children often do at the request of their parents, and their harmful effect on the child's development. It specifically describes the adverse effects of work on children's health if they leave school early and go to work immediately in factories. Dr. Bogusława Keckovą touches on this issue later in life in the text Choice of Occupation linking the occupation learned and the person's physical condition where using practical examples she shows that their disharmony has an unfavorable effect on health and life expectancy. In this regard, she also refers to a lifestyle which brings together the individual's way of life, health and life expectancy, whereby she quotes and comments on the statement by the French physiologist, Jean Pierre Flourens, ${ }^{12}$ 'A man does not die, he kills himself.'

The chapter entitled About Skin Health Care, followed by the phrase 'Cleanliness is half of health' is the fifth chapter of the article Man and His Health. Although the author begins this chapter with the medical characteristics of the skin, she presents it in a picturesque, clear and understandable way, taking care to make it easily understandable to the readers of the newspaper 'Osvit'. To present readers with the compelling importance of skin for health she states that as a

\footnotetext{
${ }^{12}$ Marie Jean Pierre Flourens (1794-1867). Yildirim FB, Sarikcioglu L. Marie Jean Pierre Flourens (1794-1867): an extraordinary scientist of his time. J Neurol Neurosurg Psychiatry. 2007;78(8):852. https:// www.ncbi.nlm.nih.gov/pmc/articles/PMC2117745/ pdf/852.pdf
}

student she attended an experiment, where her physiology professor Ludimar Herman ${ }^{13}$ covered the skin of various animals with an airtight blanket, thus preventing the physiological activities of the skin which, after a short or long time, ended with the death of the animals. In this chapter she further writes about skin care products, noting that maintenance is most important for its purity. She goes on to write about how we can best maintain the cleanliness of our skin in the easiest way and in doing so, she notes that we care the least about the cleanliness of our skin and that in general in life we do not treat any organ so mechanically in terms of reasonable and the most ordinary care as our skin. There follows a text entitled Bathing in which the author writes about the use of bathrooms in the world through the long history of human civilization, and then discusses the situation regarding baths in our cities, pointing out that they are rare and usually too expensive for poor people to use, especially in winter, and that as a result: '... thousands of people for many months, even years, do not see any baths and their skin pores are clogged.'

Dr. Bogusława Keckovą then mentions bathing children whereby she points out '... that laziness in bathing is passed on from parents to children, that children are not taught to bathe themselves because they lack public baths and bath utensils in their homes, so children stop bathing as well'. To illustrate the situation better regarding bathing children, Dr. Bogusława Keckovą states that she saw the baby of a woman who looked after a fruit orchard, who was several weeks old and had never been bathed. She concludes this observation with the sentence: 'The poor thing looked a little like a flower, its skin was wrinkled, pale, and there was barely a trace of life in it.' The next thing

\footnotetext{
${ }^{13}$ Ludimar Hermann (1838-1914) German Physiologist. Professor of Physiology, University of Zürich, 1878-1880. https://de.wikipedia.org/wiki/Ludimar_ Hermann.
} 
she describes is the importance of bathing children for their health, with specific advice. After that, we come to a text that tells us what needs to be done to improve the population's attitude to bathing, which is summarized in the sentence: 'If our people, who have been weaned from bathing, embrace bathing again, the public baths need to be restored to life, and they will be again the most important and the most blessing institutes for nurturing public health!'. To be more persuasive to the readers of the newspaper 'Osvit' Dr. Bogusława Keckova ends the chapter with a statement from 150 English doctors: '... if the cities have a sufficient number of public cold and hot baths, such as wash-hand basins, and if they work properly, the incidence of disease as well as mortality should be reduced!'

The last chapter of this article is entitled Soothing Agents in Early Childhood. It is likely that the inspiration for Dr. Bogusława Keckova to write this text was the sudden death of an infant after his mother gave him water to drink in which poppy seeds had been boiled in order to calm him down at night. The text below lists the agents that have been used to soothe infants since ancient times. In doing so, she distinguishes teas from plants that contain opium, which she considers harmful for infant health because they have a 'devastating' effect on the brain. She further explains why infants cannot sleep and why they cry, pointing out that crying is often a 'protest of nature', listing its frequent causes. She concludes that the mother may be greatly mistaken if she does not take these causes into consideration and that in such situations she should seek medical advice. The chapter concludes with a series of educational responses to the question: 'How and in what way can this widespread and deeply rooted evil in the children's world be eliminated.'

Caring for Patients at Home is the third article by Dr. Bogusława Keckovą published in 'Osvit' ${ }^{14}$ magazine in installments. At the very beginning, in the introduction, the author states in a few sentences that it is the custom for a female person to care for a patient at home, considering that this is natural and predetermined, and that in every respect the woman is capable of '.. doing this great work of loving one's neighbor.' This is followed by the first chapter, entitled The Patient's Room, which describes the importance and necessity of thinking about the patient's room in a timely manner, and not just in situations where a member of the household falls ill. In her description of what the patient's room should be like, Dr. Keckova begins with a text about Clean Air, explaining why and how the air in the room is polluted, how 'foul' air affects the patient, and how to prevent it from being polluted. Cleanliness is the following text that describes the necessity of constant maintenance of cleanliness in the patient's room. She writes the following: 'Not only the floor, but all the furniture in the room, including the ceiling and walls, should be kept at the highest cleanliness.' She also states that ceilings and walls, cracked tiles, carpets and wallpaper with many 'adornments' with rough surfaces create places for the collection of evaporated substances and dust, which gradually return into the air and are inhaled by the patient. In this process, the possibility exists of the spread of the agents of disease. This is followed by a series of practical tips on how to maintain the cleanliness of the patient's room on a daily basis, and when and how '... general cleanliness

\footnotetext{
${ }^{14}$ Keckovą B. Caring for Patients at Home. Osvit. 1905;8(38):3.; Osvit.1905;8(9):3.; Osvit.1905;8(40):3.; Osvit.1905;8(6):3.; Osvit.1905;8(12):3-4.; Osvit.1905; 8(12):4.; Osvit.1905;8(13):3.; Osvit.1905;8(45):3.; Osvit. 1905;8(45):4.; Osvit.1905;8(46):3.; Osvit.1905;8(48-49): 4.; Osvit.1905;8(22):3.; Osvit.1905;8(25):3.; Osvit.1905; 8(26):3.;Osvit.1905;8(27):3.;Osvit.1905;8(56):3.;Osvit. 1905;8(58):3.; Osvit.1905;8(59):3.; Osvit.1905;8(60):3.; Osvit.1905;8(62):3.; Osvit.1905;8(63):3.; Osvit.1905;8 (64-65):3.
} 
should be established.' The following text is about Light, in which the author talks about the importance of light in the context of patient care, citing the words 'More light,' the last words spoken by Goethe ${ }^{15}$ on his death bed. The next thing she describes is the effect of the 'marvelous power' of sunlight on all living creatures, quoting the famous folk proverb, 'Where the sun can't go, the doctor comes in'. The conditions are specifically described when doctors advise staying in a dark room because of eye ailments, when they must be hidden from daylight for the purpose of treatment. The Temperature of the Patient's Room is the following text that presents the reader with the doctor's opinion about the temperature in the room, i.e. its adjustment to the temperature of the patient and the opinion of most of the people: '... that the patient should always be kept warm, despite the differences, as far as the disease is concerned ....The author goes on to explain with practical examples that the careful care of patients with raised bodily temperature, if they are kept warm, has an adverse effect on the patient and that people's opinion that patients should always be kept warm is caused by the great fear of catching a cold. The text ends with a tip on how to maintain favorable humidity and temperature in the patient's room. The following text is about Peace in the Patient's Room, in which the author gives a range of tips for keeping peace in the patient's room, skillfully describing the situations in Bosnia-Herzegovina that create 'restlessness' and excitement in patients. Whispers or semi-silent conversations in the patient's room with those who came to visit the patient, or with the doctor, visits to the patient, cleaning the room and various noises nearby or further away are

${ }^{15}$ Johann Wolfgang von Goethe (1749-1832). German poet, playwright, novelist, scientist. https://www. britannica.com/biography/Johann-Wolfgang-vonGoethe. mentioned as situations that adversely affect the health of the patient.

In the second chapter The Patient's Bed in the opening text, entitled The Form and Construction of Beds the author points out the differences between the bed of a healthy and that of a sick person, stating that the patient's bed's shape, quality and bedding are of great importance. She describes what the patient's bed should look like in terms of practicality and the specificity of the disease. The text about Quality of Beds deals with the issue of the warmth and firmness of the bed in relation to the nature and course of the disease, that is, the patient's bodily temperature and the softness of the bed. At the end of this chapter there is a text entitled Characteristics of a Good Bed, in which it is emphasized that a good bed should be airy, light, long enough and not too cold, and the properties of the materials used to make individual parts of the bed are mentioned in relation to the disease of the patient.

The third chapter Patient Care in Bed includes four subtitles. Bedding and Bed Bases is the first text that looks at the various aspects of the physical and psychological effects of bedding and bed bases on the patient, with the aim of identifying, eliminating and preventing any negative effects on the patient's health, that is, that 'bedding and bed bases' should be in a condition that will help the physical and mental healing of the patient. What bedding, mattresses, pillows and blankets should look like, how everything should be washed and maintained is described in the text in a simple and understandable way. As in the previous chapters, in this text also, in the context of the topic, the harmful customs of the people of our region, which can have a detrimental effect on the patient, are emphasized. Bed Care is a follow-up text that begins with criticism by Dr. Keckova, referring to the placement of beds in the usual places, i.e. in the corners of the room near cold and wet walls, and in 
the context of this, in view of the assistance provided to the patients in bed, advises that in patient rooms the bed should be in the middle of the room, emphasizing the advantages of that position. This is followed by practical advice on the importance of moving the bed and adjusting it from the point of view of the patient's medical condition or mobility. The following text Patients Lying in Bed talks about the position of the body in bed, which will ease problems and contribute to the faster healing of the patient. The last text in this chapter Bed Warmers describes the importance of warming the patient's bedding and the various items that serve this purposes.

The Food and Nourishment of Patients is the fourth chapter that begins with a text entitled Food for Patients, in which the author writes about the nutrition of patients from different points of view, while pointing out the differences with respect to the diet of a healthy person. Drinks for Patients is the next text that describes the preparation and use of Chinese tea, lemonade, suma root powder and almond milk. It should be noted that nothing is mentioned in the text about these drinks in the context of various diseases, which leads the reader to the conclusion that these drinks are taken solely for the purpose of introducing fluid into the body, that is, that their curative value is not important. This chapter also contains a text entitled Measurement of Body Temperature, Pulse Checking and Measurement and Measurement of Breathing, which is presented under three headings. In the first part, entitled Measurement of Body Temperature, the author describes 'fever' as a side effect of many diseases, the reasons for its occurrence, and the way it is measured. The following text entitled Pulse Checking and Measurement talks about the importance of measuring a pulse in diagnosing a disease, how it is measured, and about its normal rate at different ages. At the end of this text, the author states that any irritability, the presence of a doctor or medical intervention in many people will greatly increase the pulse rate by 20 to 30 beats. The third text entitled Measurement of Breathing, provides instructions on the technique of counting breaths, how many there are in one minute in healthy persons in relation to their age, and situations where the number of breaths increases and when signs of activation of the accessory respiratory muscles are present.

The following chapter is the fifth chapter Bathing Patients which begins with their division into the parts of the body to be washed (full baths, half baths, sitting baths, foot baths, forearm baths and hand baths), and the temperature of the water to be used (ice baths, cold baths, lukewarm baths, warm baths, hot baths, sea baths and steam baths). For each bath mentioned Dr. Keckova describes its purpose in several sentences, how it is prepared and used, the temperature of the water to be used and its effect on the organism. The end of the text refers to 'Salt or Mineral Water Baths', 'Mud Baths', 'Iron Baths,' 'Alum Baths,' 'Sulfur Baths' and 'Pleasantly Fragrant Herbal Baths', that is, 'Baths with Admixtures (medicines)'. For each of these baths, the preparation and the amount of admixture used are described.

The sixth chapter Compresses also begins by dividing them into three types: cold, warm (warm dry and warm moist compresses), and leg compresses. For each type of compress, brief professional and informative texts describe the way they are prepared and used, and the purpose of using them. At the end of this chapter there is a text entitled Disinfection, which begins with the sentence: 'I return to cleanliness one more time and repeat that the most important aspect of patient care is cleanliness to the fullest possible extent.' To make herself even more convincing, she emphasizes to the readers in the next sentence the importance of cleanliness, stating: '... wound cleanliness is the most important 
thing in the great successes of surgery. Then, in a separate paragraph, she writes about infectious diseases and the main cause of their occurrence, that is, their source is uncleanliness transmitted in different ways from person to person, stating that it is not uncleanliness that can be 'caught by hands' or 'swept up' but it is uncleanliness in the air and fluids that can only be detected by 'a microscope. Thinking of germs, she calls them a dangerous invisible enemy. The following text describes ways infectious disease agents are transmitted to a person and what, how, when and with what they should be disinfected.

About Tuberculosis, and How It Can Be Contained is the fourth and last article by Dr. Bogusława Keckova published in the 'Osvit' ${ }^{\prime 16}$ newspaper in installments. It contains an introductory text and two chapters: Prophylaxis and School. The introductory wording begins with the proverb 'Good health is the greatest wealth!' and continues with the sentence 'Since it is the hellish and greatest enemy of our health, I consider, therefore, that the fight against tuberculosis is highly important'. With these words, Dr. Keckova already at the beginning of this article, turns her attention to tuberculosis, a serious illness at the beginning of the nineteenth century, which we simply need to combat.

She goes on to describe the history of tuberculosis, its prevalence and mortality in the world as well as its formation, duration and spread, signs that occur in the sick, pathways for tuberculosis to enter the body, the most common parts of the body that are affected by the disease, and the measures to be taken against its formation and spread.

Prophylaxis is the title of the first chapter that begins with the question: 'The question

\footnotetext{
${ }^{16}$ Keckedą B. About Tuberculosis, and How It Can Be Contained. Osvit.1906;9(4):3.; Osvit.1906;9(5):3.; Osvit.1906;9(6):3.; Osvit.1906;9(8):3.; Osvit.1906;9(9): 3.; Osvit.1906;9(4):3.; Osvit.1906;9(4):3.; Osvit.1906; 9(4):3.; Osvit.1906;9(4):3.; Osvit.1906;9(4):3.; Osvit. 1906;9(12):3.; Osvit.1906;9(13):3.
}

is certainly justified, can the body defend itself against tuberculosis?' and the answer: 'If a healthy or sick man keeps the rules mentioned here, and if by doing so keeps the most basic laws of cleanliness, the risk of infection is halved'. There follows a detailed and illustrative description of various prophylactic measures to be used by the population, with the support of the state, to keep the disease from occurring, and to reduce the number of tuberculosis patients, emphasizing that all these measures and instructions are in vain if they remain merely on paper.

Chapter two of this article is entitled 'School' and describes school as a convenient place where the application of preventive measures will begin to be used. She says '... modern health science is turning to youth, because to strengthen youth means to cultivate a better generation of human beings in the future'. In the next sentence, she states: '... that there is no 'Institution' so convenient for tuberculosis to be decisively and with a such great success destroyed as a school.'

Dr. Keckova supports these claims with statistical data indicating that the incidence of tuberculosis among school children was steadily increasing and states that this could not be attributed to uncleanliness and other circumstances in the home, but that one must believe 'that the school itself is where tuberculosis is being spread' and that it is the duty of the state to take care of the fact, '... that the situation where children spend their day is such that they do not suffer any harm to their health.' One part of this text is dedicated to the general health education of school children as well as their training regarding tuberculosis stating that children should be told that '... blowing their nose on the floor or spitting are nasty and dangerous habits and it must be explained why it is written on the walls: 'It is forbidden to spit on the floor!' 
She goes on to explain in detail why tuberculosis is a common disease in children, how it comes about and what can be done to prevent it in schools, explaining how this procedure should be applied and what benefit the procedure brings, and what happens if it is not applied. In addition, there are positive examples of schools from abroad (France) and their role in the suppression and prevention of tuberculosis.

In the last two shorter installments of this article Dr. Keckovą refers critically from a medical point of view to the burden on children in terms of the subject matter they need to learn in school, the time burden of school activities, and the working conditions in their schools, stating examples of diseases and conditions in children which result from the burden on children and the inconsistencies in our schools.

This article by Dr. Keckovą ends with a request based on the previous text '... that basic training must be changed immediately and fundamentally. Her thinking, about changes in schools is expressed in the final sentence of this article: 'Maybe these desires in this country and elsewhere would be quickly met, if the highly necessary and beneficial institution of school doctors was introduced and if there was sincere will and support in municipalities', and is worth attention because she sees the solution to all the difficulties which contribute to the disruption of the school children health in the establishment of the institution of school doctor. 